\title{
Talent Management and Employee Retention: The Partial Mediating Role of Organizational Commitment
}

\author{
Muhamad Ekhsan ${ }^{1}$, Ryani Dhyan Parashakti ${ }^{2}$, Achmad Sudiro ${ }^{3}$ \\ \{muhamad.ekhsan@pelitabangsa.ac.id ${ }^{1}$,ryani.dhyan.parashakti@undira.ac.id², \\ achmadsudiro@yahoo.com ${ }^{3}$ \} \\ Management Department, Faculty of Economy and Business, University \\ Pelita Bangsa, Bekasi, West Java, Indonesia ${ }^{1}$, Management Department, Faculty of \\ Economy and Business, University Dian Nusantara, West Jakarta, Jakarta, \\ Indonesia ${ }^{2}$, Management Department, Faculty of Economy and Business, University \\ Brawijaya, Malang, East Java, Indonesia ${ }^{3}$
}

\begin{abstract}
Employee retention is the biggest challenge faced by human capital management in the modern and digital economy. Due to a growing shortage of talented employees, organizations are looking for comprehensive strategies to attract and retain potential employees. Talent management as employee management has a strategic role in retaining employees, as well as building organizational commitment. This study aims to determine the effect of talent management on employee retention through organizational commitment as a mediating variable. This research was conducted at a company based on agricultural technology in Cikarang. This study uses the census method in determining a sample of 83 respondents. This research uses partial least square method structure equation modeling (PLS-SEM). The result of this research shows the partial mediating model hypothesised was supported by the SEM model, indicating that retention management require both good talent management and a good organizational commitment.
\end{abstract}

Keywords: Talent Management, Organizational Commitment, Employee Retention

\section{Introduction}

Human resources are the most important asset in gaining competitive and sustainable advantage and efficiency[1]. In line with this, organizations need to be wise in paying attention to their human resources, especially human resources who are considered talented and have the potential to provide progress towards the existence of the company or known as talented employees[2]. In addition, human resource managers must have good retention management. High employee retention will affect organizational performance in achieving organizational goals and missions[3]. High employee retention is needed in terms of improving employee performance[4]. If employee retention is weak, it will increase turnover which may negatively have an effect on company performance and effectiveness. Maintaining high employee retention will be able to increase the effectiveness and performance of the company because with high retention, of course, turnover will be low [5]. Low turnover saves selection and recruitment costs. Knowledge of employee retention can be a source of competitive advantage for companies. One 
of the greatest benefits of talent management is the effect it has on the hiring and retention of valuable employees [6].

The success of any company's retention management depends on a human capital management strategy in place to ensure they retain talented employees. The challenge faced by human capital management today is getting employees to continue to be involved in company activities and also ensuring the interest of talented employees to join the company and retain talented employees in the company[7]. If employee retention is weak, then employee turnover will increase and have a negative effect on the performance and effectiveness of the company. Maintaining employee retention levels is believed to have an influence on the effectiveness and performance of a company, because with high employee retention, thus employee turnover in a company is low[5]. From all of the above opinions, it can be concluded that employee retention is the biggest challenge faced by human capital management in the modern and digital economy.

In Indonesia, regarding the trend of employee turnover in the next 12 months, almost a quarter of respondents $(72 \%)$ provided information that employees might think about changing their jobs in the next 12 months [8]. This information can be seen in the image below:

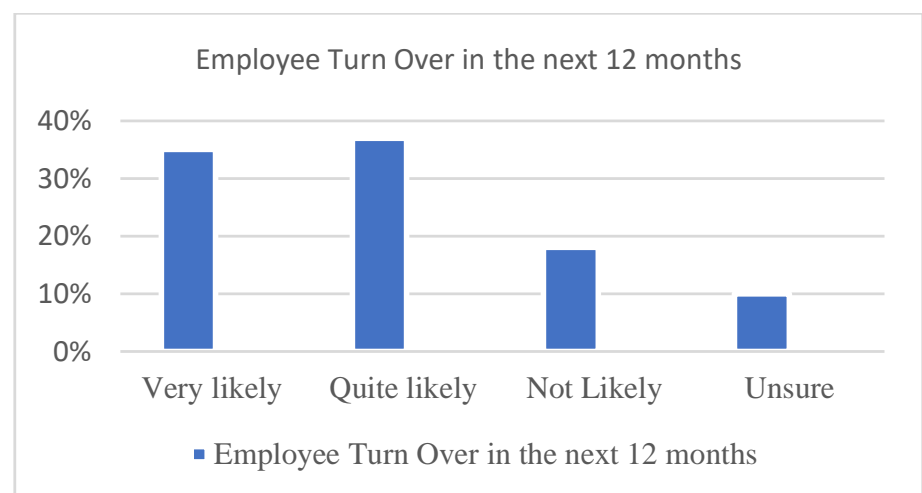

Figure 1 Trend of employee turnover in Indonesia in the next 12 months (2015)

Source: Michael Page Indonesia Employee Intentions Report 2015

From the research data[8] regarding the turnover trend in Indonesia, it was found that every employee began to think about leaving a company to move to another company after 12 months of work.

Today's organizations are challenged by social developments such as globalization, improved technology and increasing global competition. Companies must be able to anticipate technological innovations and compete with other companies around the world. Apart from economic evolution, demographic changes have also put pressure on companies. Today's society has to deal with the rapid aging of the active population while, meanwhile, fewer young people enter the labor market, even the workers of the so called baby boomers are gradually retiring[9]. This evolution has not only led to a shortage of workers, but also the risk of losing knowledge and experience, which companies must answer. This loss of knowledge and experience increases the importance of retaining talent. Talent as a vehicle to move the organization where it wants to be[9]

Talent management is now very important. Other interesting data related to talent management can be seen from the research results[10] which reveals some interesting things that talented employees and leadership are increasingly scarce. Fewer qualified employees and leaders are entering the workforce to replace aging, retiring leaders[10]. Given the growing 
shortage of talent, organizations are looking for a comprehensive strategy to attract and retain current potential employees[11] [12].

Organizational commitment is one of the keys to maintaining employee performance[13]. The organization will run well when it is supported by talent management and organizational commitment. Organizational commitment is defined by some researchers as a measure of the strength of an employee's identity and involvement in the goals and values of the organization[14]. Organizational commitment as an attitude that reflects employee loyalty to the organization and is an ongoing process, where organizational members express their concern for the organization, for organizational success and continuous progress.[15]. A committed employee shows loyalty, a psychological attachment to work and identifies with organizational goals[16]. Research shows that employees with strong organizational commitment are valuable assets of an organization. As a committed workforce, they can ensure the improvement and performance of the organization's productivity and competitiveness[17]. The empirical findings show organizational commitment affects the rate of retention in organizations[18]

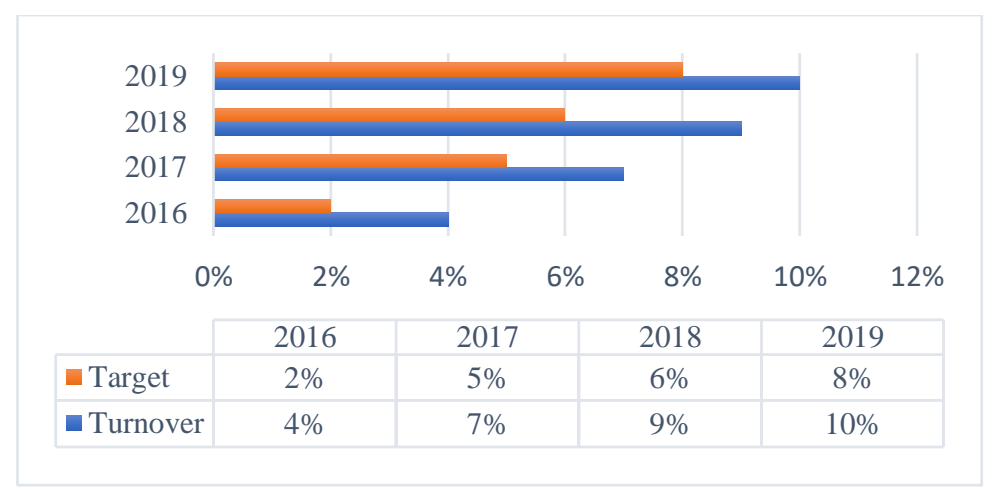

Figure 2. Employee Turnover Chart

Figure 2 employee turnover chart provides an explanation that there is an increase in employee turnover, this is in accordance with the initial explanation that the majority of company employees are engaged in agricultural technology in Cikarang. Currently is the millennial generation, in previous studies the millennial generation has a low retention rate and it is easy to make decisions to move companies because the compensation factor is the main thing, as research on employee retention in Indonesia [8].

\section{Literature Review}

\subsection{Employee Retention}

Employee Retention is a situation where employees within the organization want to stay in the organization where they work [19]. This makes the company have to maximize retention by maximizing the number of employees in the company who really want to stay in the company, not because of coercion from the company. Employee retention has become a major topic of discussion in the academic literature of Human Resource Management today and has become increasingly important as knowledge has developed into a major corporate asset[20]. Employee retention is generally defined as the ability to maintain a stable human resource. This is often associated with organizational passion and trust. 


\subsection{Talent management}

Talent management is one of the most important factors in ensuring the continued success of an organization[21]. Talent management is a term that covers more than a series of activities, such as succession planning, employee loyalty, employee trust, human resource planning, employee performance managemen [22]. Talent management is defined as a systematic and dynamic and the process of finding, developing, and retaining talent. A very important part of a talent management strategy is retaining and developing talented individuals [23].

\subsection{Organizational Commitment}

Organizational commitment is defined as a feeling of an employee's obligation to remain with the organization, a feeling that results from internalizing the normative pressure exerted on individuals before entering or participating in an organizational activity[24]. Organizational commitment can take three different forms. Affective commitment refers to identification with, involvement in, and emotional attachment to the organization, in the sense that employees with strong affective commitment stay with the organization because they want to do so [25]. Ongoing commitment refers to a commitment based on the employee's recognition of the costs associated with leaving the organization. Commitment as a form of loyalty to the organization which in a long time will produce organizational citizenship, namely behavior that is useful in the organization without having to be demanded by job descriptions or orders from superiors [26].

\section{Methods}

This quantitative descriptive study was followed by an inductive research approach and a survey-based research strategy. The methodology chosen for this research is quantitative. The survey is collected through the required quantitative information and the data is collected through a structured questionnaire. A literature review was conducted to identify the variable talent management, employee retention and organizational commitment. The questionnaire was developed based on variable identification. The sampling technique in this study used saturated samples, about a total of 83 employees from the technical department of agricultural technologybased companies in Cikarang. The sampling technique using google form was in filling out online surveys, further strengthening the research results with descriptive analysis, direct interviews in the form of a Forum Group Discussion. The method used is a quantitative method with SEM Smart PLS software as an analysis tool. To analyze the effect of talent management on employee retention, the influence of talent management on organizational commitment, the influence of organizational commitment on employee retention, the influence of talent management on employee retention mediated by organization commitment. Thus, the hypothesis is the influence of talent management on employee retention mediated by organization a commitment. Thus, the hypothesis is the influence of talent management on employee retention mediated by organization a commitment. Thus, the hypothesis is :

H1: Talent Management affects employee retention

H2: Talent Management affects organizational commitment

H3: Organizational commitment affects employee retention

H4: Talent Management affects employee retention mediated by Organizational Commitment 


\section{Result and Discussion}

\subsection{Testing the Structular Model (Inner Model)}

This test is a test of a structural model by looking at the value of the R-square which is the result of the goodness of fit model test. The talent management model for employee retention provides an R-square value of 0.430 which can be interpreted that the variability of the Employee Retention construct can be explained by the talent management construct variable of $43.0 \%$ while $37.0 \%$ is explained by other variables outside of this study. Another influence model is the Organizational Commitement variable with the indicated value of 0.670 so it can be interpreted that $67.0 \%$ of organizational commitment constructs with the dependent variable, namely talent management and employee retention. Meanwhile, $33.0 \%$ is explained by other variables that are not included in this study. Can be seen in the table below:

Table 1. R-Square

\begin{tabular}{cc}
\hline Variable & R Square \\
\hline Employee Retention & 0.430 \\
\hline Organizational Commitment & 0.670 \\
\hline
\end{tabular}

After the determination test, a path analysis is carried out to determine the causal relationship between exogenous and endogenous variables by bootstrapping smart PLS 3.0 to get predictions from the path analysis results in this model.

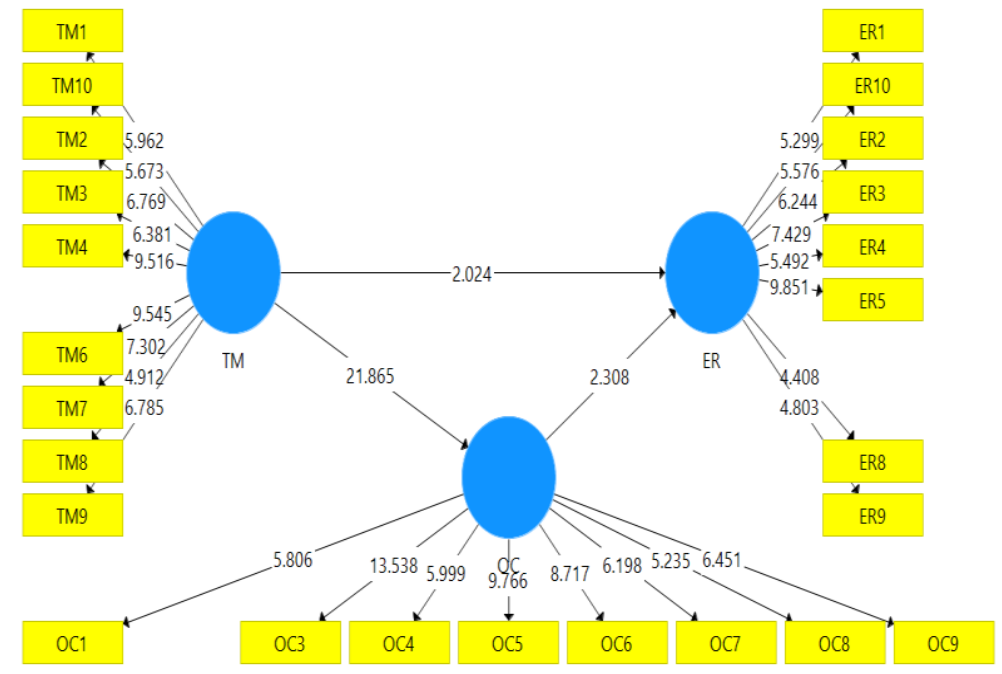

Figure 2 Bootstrapping Output

Source: Researcher (2020)

For more details, detailed in table 2 the path coefficient, which explains the coefficient value of the $\mathrm{T}$ value and $\mathrm{P}$ value to be a reference for the caseal relationship in this model. 
Table 2. Path Coefficient

\begin{tabular}{|c|c|c|c|c|c|}
\hline Variable & $\begin{array}{l}\text { Original } \\
\text { Sample } \\
(0)\end{array}$ & $\begin{array}{l}\text { Sample } \\
\text { Mean } \\
\text { (M) }\end{array}$ & $\begin{array}{l}\text { Standard } \\
\text { Deviation } \\
\text { (STDEV) }\end{array}$ & $\begin{array}{c}\mathbf{T} \\
\text { Statistics } \\
\text { (| O / } \\
\text { STDEV } \\
\text { |) }\end{array}$ & $\begin{array}{c}\mathbf{P} \\
\text { Values }\end{array}$ \\
\hline $\begin{array}{c}\text { Talent Management - } \\
>\text { Employee } \\
\text { Retention }\end{array}$ & 0.353 & 0.358 & 0.174 & 2,024 & 0.043 \\
\hline $\begin{array}{c}\text { Talent Management -> } \\
\text { Organizational } \\
\text { Commitment }\end{array}$ & 0819 & 0826 & 0.037 & 21,865 & 0.000 \\
\hline $\begin{array}{c}\text { Organizational } \\
\text { Commitment -> } \\
\text { Employee Retention }\end{array}$ & 0.335 & 0.350 & 0.145 & 2,308 & 0.021 \\
\hline
\end{tabular}

Based on table 2. path coeffiecient which explains the direct effect, then table 3 specific indirect explains the indirect effect.

Table 3.Specific Indirect Effects

\begin{tabular}{|c|c|c|c|c|c|}
\hline Variable & $\begin{array}{c}\text { Original } \\
\text { Sample } \\
(\mathbf{O})\end{array}$ & $\begin{array}{c}\text { Sample } \\
\text { Mean } \\
\text { (M) }\end{array}$ & $\begin{array}{l}\text { Standard } \\
\text { Deviation } \\
\text { (STDEV) }\end{array}$ & $\begin{array}{c}\text { T } \\
\text { Statistics } \\
\text { (| O / } \\
\text { STDEV } \\
\text { |) }\end{array}$ & $\begin{array}{c}\text { P } \\
\text { Values }\end{array}$ \\
\hline $\begin{array}{c}\text { Talent Management } \\
\text {-> Employee } \\
\text { Retention -> } \\
\text { Organizational } \\
\text { Commitment }\end{array}$ & 0.274 & 0.292 & 0.128 & 2,139 & 0.033 \\
\hline
\end{tabular}

Talent management variable has a positive and significant influence on employee retention variables. So this means that the higher the talent management variable, the higher the value of employee retention. This research is also in line with research[27] who said that there was a significant influence between talent management variables on employee retention. Talent Management is a strategic approach to ensure an organization is able to achieve its goals, one of which is by reducing the turnover rate.

Talent management variable has a positive and significant influence on the organizational commitment variable. So this means that the higher the talent management variable, the higher the organizational commitment. This research is also in line with research[28] the mission and responsibility of the organization is to create a policy strategy for developing a vision. Meanwhile, talent management is not only intended to maximize organizational performance, but also talent management has a positive influence on organizational commitment.

The organizational commitment variable has a positive and significant effect on the employee retention variable. So this means that the higher the organizational commitment variable, the 
higher the employee retention will be. This research is also in line with research[17] who said that there was a significant influence between the variable organizational commitment on employee retention. A committed employee shows loyalty, thereby increasing employee retention

The talent management variable has a positive and significant influence on the employee retention variable through mediating organizational commitment. So this means that the higher the variable talent management and organizational commitment, the higher the employee retention variable. This research is also in line with research[29] who said that there was a significant influence between talent management variables on employee retention mediated by organizational commitment. Increased talent management affects employee retention through high organizational commitment in the organization.

\section{Conclusion}

Based on the results of research that discusses the effect of talent management on employee retention mediated by organizational commitment to agricultural technology companies in Cikarang, it can be concluded:

a. Talent management affects employee retention. the more talent management the employees have, the higher the employee retention.

b. Talent management affects organizational commitment. The more telent management on employees, the better the organizational commitment to the organization.

c. Organizational commitment affects employee retention. The higher the employee's organizational commitment to the company, the higher the employee retention.

d. Talent management affects employee retention which is mediated by organizational commitment. Increasing talent management and organizational commitment to employees, the employee retention will increase

\section{References}

[1] M. Pasban and S. H. Nojedeh, "A Review of the Role of Human Capital in the Organization," Procedia-social Behav. Sci., vol. 230, pp. 249-253, 2016.

[2] E. Gallardo-Gallardo, N. Dries, and T. F. González-Cruz, "What is the meaning of "talent'in the world of work?," Hum. Resour. Manag. Rev., vol. 23, no. 4, pp. 290-300, 2013.

[3] F. Malik, L. McKie, R. Beattie, and G. Hogg, “A toolkit to support human resource practice," Pers. Rev., vol. 39, no. 3, pp. 287-307, 2010.

[4] M. Sumarni, "Pengaruh employee retention terhadap turnover intention dan kinerja karyawan," Akmenika UPY, vol. 8, pp. 20-47, 2011.

[5] G. L. Yurika, "Analisis Manajemen Karir, Lingkungan Kerja dan Kpepuasan Kerja Terhadap Retensi Karyawan Serta Dampaknya terhadap Kinerja Perusahaan Pada PT. Origa Mulia FRP," Universitas Bina Nusantara, 2011.

[6] K. Hasani and S. Sheikhesmaeili, "Knowledge management and employee empowerment," Kybernetes, 2016.

[7] S. K. Kigo and G. Hazel, "Effect of Talent Management Strategies on Employee Retention in the Insurance Industy," Strateg. J. Bus. Chang. Manag., 2016.

[8] Michael Page, "2015 Employee Intentions Report Indonesia," 2015.

[9] N. Govaerts, E. Kyndt, F. Dochy, and H. Baert, "Influence of learning and working climate on the retention of talented employees," J. Work. Learn., 2011.

[10] McKinsey \& Company, "The State of Human Capital 2012. False Summit," 2012.

[11] M. Guthridge, A. B. Komm, and E. Lawson, "Making talent a strategic priority," McKinsey Q., 2008. 
[12] P. R. Newswire, "Baxter International Inc. and ManpowerGroup Recognized for Exemplary Corporate Diversity and Inclusion Practices," Chicago-United-Awards. 2014.

[13] R. V Dhanalakshmi and K. B. Gurunathan, "A study on talent management as a strategy to influence employee engagement and its affect on the organizational outcome," Int. J. Bus. Adm. Res. Rev., vol. 2, no. 4, pp. 183-186, 2014.

[14] M. A. Khan, "Organizational cynicism and employee turnover intention: Evidence from banking sector in Pakistan," Pakistan J. Commer. Soc. Sci., vol. 8, no. 1, pp. 30-41, 2014.

[15] A. U. Hasanah and S. Suharnomo, "Pengaruh Time Demands Of Work Terhadap Kepuasan Kerja, Stress Kerja, Dan Turnover Intention Karyawan (Studi Pada Karyawan Pt. Bank Tabungan Negara (Persero) Tbk. Cabang Harapan Indah, Bekasi),” Diponegoro J. Manag., vol. 5, no. 3, pp. 80-91, 2016.

[16] C. Bulut and O. Culha, "The effects of organizational training on organizational commitment," Int. J. Train. Dev., vol. 14, no. 4, pp. 309-322, 2010.

[17] P. K. Mahal, "HR practices as determinants of organizational commitment and employee retention," IUP J. Manag. Res., vol. 11, no. 4, p. 37, 2012.

[18] P. C. Morrow, "Managing organizational commitment: Insights from longitudinal research,” $J$. Vocat. Behav., vol. 79, no. 1, pp. 18-35, 2011.

[19] R. P. Finnegan, The Power of Stay Interviews for Engagement and Retention. Society for Human Resource Management, 2012.

[20] P. Horn and R. Griffeth, "Employee Turnover, Cincinnati," OH South-Western Publ., 1995.

[21] A. McDonnell, "Still fighting the "war for talent'? Bridging the science versus practice gap," J. Bus. Psychol., vol. 26, no. 2, pp. 169-173, 2011.

[22] D. Hartley, "Tools for talent," T D, vol. 58, no. 4, pp. 20-22, 2004.

[23] J. Chaisson and A. Schweyer, "Global talent management: Fostering global workforce practices that are scalable, sustainable and ethical," A Hum. Cap. Inst. Position Pap. Spons. by Taleo. June. Available www. Res. com/documents/Global\% 20Talent\% 20Management. pdf, 2004.

[24] N. J. Allen and J. P. Meyer, "The measurement and antecedents of affective, continuance and normative commitment to the organization," J. Occup. Psychol., vol. 63, no. 1, pp. 1-18, 1990.

[25] J. P. Meyer and N. J. Allen, "A three-component conceptualization of organizational commitment," Hum. Resour. Manag. Rev., vol. 1, no. 1, pp. 61-89, 1991.

[26] M. Armstrong and S. Taylor, Armstrong's handbook of human resource management practice. Kogan Page Publishers, 2020.

[27] V. Oladapo, "The impact of talent management on retention," J. Bus. Stud. Q., vol. 5, no. 3, p. 19, 2014.

[28] F. Vural, A. A. Dura, Ş. Fil, S. Çiftçi, S. D. Torun, and R. Patan, "The Factors Effecting Healthcare Employees Satisfaction, Retention And Organizational Commitment," Balikesir Helath Sci. J., vol. 1, no. 3, pp. 137-144, 2012.

[29] C. N. Arasanmi and A. Krishna, "Employer branding: perceived organisational support and employee retention-the mediating role of organisational commitment," Ind. Commer. Train., 2019. 